http://jmscr.igmpublication.org/home/ ISSN (e)-2347-176x ISSN (p) 2455-0450

crossref DOI: https://dx.doi.org/10.18535/jmscr/v7i12.64

\author{
Journal Of Medical Science And Clinical Research \\ IGM Publication \\ An official Publication of IGM Publication
}

\title{
Assessment of C-peptide levels in Diabetes mellitus patients and their association with obesity
}

\author{
Authors \\ Dr Darshana Jain ${ }^{1}$, Dr Fatima Bhopalwala ${ }^{2 *}$ \\ ${ }^{1}$ Assistant Professor, Department of Biochemistry, Government Medical College, Ratlam, India \\ ${ }^{2}$ Assistant Professor, Department of Anatomy, Government Medical College, Ratlam, India \\ *Corresponding Author \\ Dr Fatima Bhopalwala \\ Assistant Professor, Department of Anatomy, Government Medical College, Ratlam, India
}

\begin{abstract}
Background: Diabetes mellitus is a chronic metabolic and endocrine disorder resulting from defects in insulin secretion, insulin action or both. The determination of c-peptide provides an assessment of endogenous secretory reserves in patients with diabetes mellitus and is considered a more reliable indicator of insulin secretion than insulin itself.

Objective: To estimate the $C$-peptide levels in type 2 diabetics; to assess the endogenous insulin secretary function and to find their association with obesity.

Material and Method: The present study was conducted on 100 adult patients of type 2 Diabetes mellitus presenting in OPD and emergency after taking informed consent and approval from hospital ethical committee. Venous blood sample were withdrawn in the fasting state and C-peptide levels were estimated. Results: Out of 100 patients, $49 \%$ patients had fasting C-peptide levels between 1-2 $\mathrm{ng} / \mathrm{ml}$. Only $7 \%$ patients had $<0.6 \mathrm{ng} / \mathrm{ml}$. The mean fasting-peptide level of the study was $1.348 \pm 0.796$.

Conclusion: Raised levels of $C$-peptide seen in diabetic patients as the resistance to insulin increases hence it can be used as a screening tool.
\end{abstract}

Keywords: Diabetes Mellitus, C-peptide, Insulin.

\section{Introduction}

Diabetes mellitus characterized by chronic hyperglycemia with disturbances of carbohydrate, fat and protein metabolism. ${ }^{[1]}$ It is a major cause of mortality and morbidity worldwide. The incidence of this disorder is increasing worldwide. ${ }^{[2]}$ Human insulin and C-peptide are synthesized as a single polypeptide chain known as proinsulin in the pancreatic islet by the beta cells. ${ }^{[3]}$ The great interest in C-peptide is due to the limitations of the use of serum insulin as a measure of insulin secretion because insulin after its secretion into the portal vein passes through the liver where approximately $50 \%$ of the delivered insulin is extracted. ${ }^{[4]}$ The measurement of C-peptide, which is co-secreted with insulin from beta cells of pancreas, thus provides a better index of endogenous insulin production and pancreatic beta cell function than insulin measurement. ${ }^{[5]}$ Keeping this perspective in mind, this study was conducted to assess the Cpeptide level and its association with obesity in a randomized sample of patients with type 2 diabetes. 


\section{Material and Method}

The present study was conducted on 100 adult patients of known type 2 diabetes mellitus presenting in outpatient department and emergency room after taking informed consent and approval from hospital ethical committee. Patient already taking oral hypoglycaemic agents were asked to stop the drugs for 3 days. The patients were asked to come in the fasting state. After taking weight and height for calculation of BMI, venous blood samples were withdrawn in the fasting state and fasting blood glucose levels and C-peptide levels were estimated. Patient with DM-1, acute infections, renal failure, and pregnancy were excluded from the study. For estimation of C-peptide chemiluminescence immunoassay was used.

\section{Results}

Out of 100 patients with type 2 diabetes mellitus in the present study, a maximum of 38 patients were between the age groups of 50-59 years, followed by 36 patients in the age group of 40-49 years. 16 patients out of 100 study patients were in the age group of 30-39 years. 10 were in the age group of 60-69 years. Mean age group in present study was 49.01 \pm 9.121 . Table. 1 shows age wise distribution of cases.

Table. 1 Age wise distribution of subjects

\begin{tabular}{|c|c|}
\hline Age Groups & Number of Patients \\
\hline $30-39$ & 16 \\
\hline $40-49$ & 36 \\
\hline $50-59$ & 38 \\
\hline $60-69$ & 10 \\
\hline
\end{tabular}

Table. 2 Sex wise distribution of subjects

\begin{tabular}{|l|c|}
\hline Sex & Frequency \\
\hline Male & $58 \%$ \\
\hline Female & $42 \%$ \\
\hline
\end{tabular}

table. 2 shows that out of 100 patients of type 2 diabetes, $42 \%$ patients were females, while $58 \%$ were males. The male: female ratio in the present study with type 2 diabetes mellitus was 1.38:1.

Table. 3 Fasting C-Peptide Levels in DM-2

\begin{tabular}{|l|c|}
\hline Fasting C-Peptide Level $\mathbf{~ n g} / \mathbf{m l}$ & Number of Patients \\
\hline$<0.1$ & 3 \\
\hline $0.1-0.5$ & 4 \\
\hline $0.6-0.9$ & 27 \\
\hline
\end{tabular}

\begin{tabular}{|l|c|}
\hline $1-2$ & 49 \\
\hline$\geq 2$ & 17 \\
\hline Total & 100 \\
\hline
\end{tabular}

Table. 3 shows the levels of fasting C-peptide in the present study. Out of 100 patients, 49\% patients had fasting C-peptide levels between 1-2 ng/ml, $27 \%$ patients had fasting C-peptide levels between 0.6$0.9 \mathrm{ng} / \mathrm{ml}$ and $17 \%$ patients had $>2 \mathrm{ng} / \mathrm{ml}$. Only $7 \%$ patients had $<0.6 \mathrm{ng} / \mathrm{ml}$. The mean fasting Cpeptide level of the study was $1.348 \pm 0.796$.

Table. 4 Fasting Blood Sugar Levels in DM-2

\begin{tabular}{|l|c|}
\hline FBS Level in mg/dl & Number of Patients \\
\hline$<200$ & $26 \%$ \\
\hline $200-250$ & $56 \%$ \\
\hline$>250$ & $18 \%$ \\
\hline & 100 \\
\hline
\end{tabular}

Table. 4 shows that out of 100 patients in the present study with type 2 diabetes, $56 \%$ patients had fasting plasma glucose level between $200-250 \mathrm{mg} / \mathrm{dl}$, $25 \%$ patients had $<200 \mathrm{mg} / \mathrm{dl}$ and $18 \%$ patients had $\geq 250 \mathrm{mg} / \mathrm{dl}$. So the study shows that majority of the patients (42) patients had fasting plasma glucose levels between $200-250 \mathrm{mg} / \mathrm{dl}$. The mean plasma glucose level of the study was $223.10 \pm 29.93$.

Table 5 Association of C-peptide with Obesity

\begin{tabular}{|l|c|c|c|c|c|c|}
\hline BMI & \multicolumn{7}{|c|}{ Fasting C- peptide } \\
\hline & $<\mathbf{0 . 1}$ & $\mathbf{0 . 1 - 0 . 5}$ & $\mathbf{0 . 6 - 0 . 9}$ & $\mathbf{1 - 2}$ & $\geq \mathbf{2}$ & Total \\
\hline$<\mathbf{2 5}$ & 3 & 4 & 20 & 29 & 2 & 58 \\
\hline$\geq \mathbf{2 5}$ & 0 & 0 & 7 & 20 & 15 & 42 \\
\hline Total & 3 & 4 & 27 & 49 & 17 & 100 \\
\hline
\end{tabular}

Table. 5 shows that as the BMI value of the patient increases, the fasting C-peptide level also increases. Also shows that BMI values and the levels of fasting C-peptide are highly associated. As the BMI increases the fasting c- peptide levels increases, though not in a linear fashion.

\section{Discussion}

The age group of the study patients range from 3070 years. The age group with maximum number of patients was 50-60 years. The mean age of the study group is $49.01 \pm 9.121$. Bilal Bin abdullah et al in their study showed that most of the diabetes was in the age group of 50-60 years. ${ }^{[6]}$ Similarly Khatib et al also in their study showed that most of the diabetes was in the age group of 50-60 years. ${ }^{[7]}$ 
In present study population, most of the patients were males (58\%) compared to female (42\%). Thus indicating prevalence of type $2 \mathrm{DM}$ is much more in male as compared to female. Yadav N K et al had $70 \%$ of study population males and $30 \%$ females. ${ }^{[8]}$ Previously several studies in India (Ajagnakar and Sathi et al, Vaishnava et al, and Shankar et al) have reported the similar incidence of diabetes. Based on BMI, $42 \%$ of the studied patients were obese as per American Diabetic Association, Clinical Practice Recommendation 20/02/12. The number of non obese patients was $56 \%$. In our study we observe that the fasting C-peptide levels were higher in the obese patients than in the non obese patients. Hence this study suggests that obese patients are hyperinsulinemic. Majority of patients have adequate insulin reserve as shown by C-peptide levels. Similar results were observed by Abdullah B et al in their study. C. Snehalatha, A. Ramachandran et al conducted a study analysing the insulin secretion in Asian Indians also observed lesser insulin levels in non obese compared to obese. ${ }^{[9]}$

\section{Conclusion}

we can conclude that duration of diabetes and insulin reserve travels in opposite direction which is shown by beta cell function deterioration with duration of diabetes this is also supported by reduce level of c-peptide with increase in duration of diabetes. Our study shows resistance to insulin is seen in obese patients which is quite evident from raised C-peptide level. So from these observations we suggest increased use of $\mathrm{C}$-peptide level assessment as a tool for screening and guiding treatment in diabetic patients.

\section{Acknowledgement}

We would like to thank our patients and our technical staff for their support. Financial support and sponsorship are nil. There are no conflicts of interest.

\section{References}

1. Chowta MN, Adhikari PM, Chowta NK, Shenoy AK, D’Souza S. Serum C-peptide level and renal function in diabetes mellitus. Indian Journal of Nephrology 2010; 20(1):25-27.

2. Ramachandran A, Snehalatha C, Kapur A. Diabetes epidemiology study in india (desi). High prevalence of diabetes and IGT in india: national urban diabetes survey. Diabetologia. 2001;44:1094-10.

3. Ashby TD, Frier BM. Circulating c-peptide measurement and clinical application. Annals ClinBiochem. 1981;18:125.

4. Ferranini E, Cobelli C. The kinetics of insulin in man. Role of the liver. Diabetes Metab Rev 1987;3:365-97

5. Tura A, Ludvik B, Nolan JJ, Pacini G, Thomaseth K. Insulin and C-peptide secretion and kinetics in humans: direct and model-based measurements during OGTT. Am J Physio-Endocrinol Metabolism. 2001;281(5):E966-74.

6. Abdullah B, Patil B, Thaseen A. Significance of $\mathrm{C}$-peptide in Type 2 diabetics-A study in the north karnataka population of India. Al Ameen J Med Sci 2010;3(1):65-78.

7. Nazli M Khatib, Zahiruddin S Quazi, et al. Risk factors of type 2 diabetes mellitus in rural Wardha: A community based study. Int J Diab Dev 2008; 28 (3): 79-82.

8. Yadav NK, Thanpari C, Shrewastwa MK, Mittal RK "Comparison of Lipid profile in Type-2 Obese Diabetics and Obese Nondiabetic Individuals. A hospital Based Study from Western Nepal" kathmandu university medical journal 2012; vol.10 (3) issue 39 julsep.44-7.

9. Snehalatha C, Satyavani K, Ramachandran $\mathrm{A}$, et al. Insulin secretion and action in different stages of glucose tolerance in Asian Indians. Diabet Med 1999 ;16:408-414. 